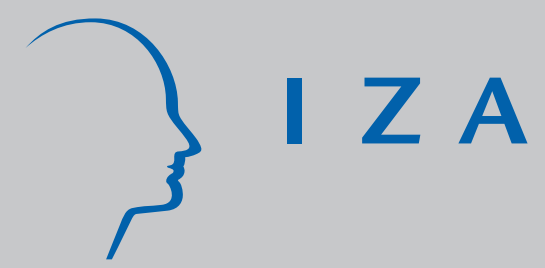

IZA DP No. 9824

Moral-Hazard-Free First-Best Unemployment Insurance

Donald O. Parsons

March 2016

Forschungsinstitut zur Zukunft der Arbeit Institute for the Study of Labor 


\title{
Moral-Hazard-Free First-Best Unemployment Insurance
}

\author{
Donald O. Parsons \\ George Washington University \\ and IZA
}

Discussion Paper No. 9824

March 2016

\author{
IZA \\ P.O. Box 7240 \\ 53072 Bonn \\ Germany
}

Phone: +49-228-3894-0

Fax: +49-228-3894-180

E-mail: iza@iza.org

\begin{abstract}
Any opinions expressed here are those of the author(s) and not those of IZA. Research published in this series may include views on policy, but the institute itself takes no institutional policy positions. The IZA research network is committed to the IZA Guiding Principles of Research Integrity.

The Institute for the Study of Labor (IZA) in Bonn is a local and virtual international research center and a place of communication between science, politics and business. IZA is an independent nonprofit organization supported by Deutsche Post Foundation. The center is associated with the University of Bonn and offers a stimulating research environment through its international network, workshops and conferences, data service, project support, research visits and doctoral program. IZA engages in (i) original and internationally competitive research in all fields of labor economics, (ii) development of policy concepts, and (iii) dissemination of research results and concepts to the interested public.
\end{abstract}

IZA Discussion Papers often represent preliminary work and are circulated to encourage discussion. Citation of such a paper should account for its provisional character. A revised version may be available directly from the author. 


\section{ABSTRACT \\ Moral-Hazard-Free First-Best Unemployment Insurance*}

Unemployment insurance replacement rates world-wide are well below 100 percent, a fact often attributed to search moral hazard concerns. As Blanchard and Tirole (2008) have illustrated, however, neither search nor layoff moral hazard (firing cost) distortions need arise in first-best insurance plans. Their counterexample depends on the functional form of the state utility function--utility with a single argument, consumption plus monetized leisure. The monetized leisure model is unattractive if leisure is a choice variable, however, and a review of the optimal UI literature reveals a surprising variety of alternative utility function assumptions. A standard neoclassical utility function is used to characterize the utility function conditions required to generate moral-hazard-free (MHF) first-best contracts. Two conditions emerge: (i) the necessary condition that leisure and consumption be substitutes (the cross-derivative of consumption and leisure be negative) and (ii) the sufficient condition that leisure be an inferior good, Rosen (1985). Leisure appears to be a normal good, which rules out the possibility of first-best moral-hazard-free (FB MHF) utility structures, but the firstbest UI replacement rate remains very much an open question. The rich empirical literature on the "retirement consumption paradox" suggests that the rate is below 100 percent, easing moral hazard concerns, if not eliminating them.

JEL Classification: J65, J41, J33, J08

Keywords: unemployment insurance, utility functions, moral hazard, firing costs, consumption, retirement

Corresponding author:

Donald O. Parsons

Economics Department

George Washington University

2115 G Street NW, Monroe 368

Washington, DC 20052

USA

E-mail: dopars@gwu.edu

\footnotetext{
* This paper evolved from a casual conversation with Carmen Pagés, who bears no responsibility for the consequences. It is dedicated to the memory of a mentor and friend, Sherwin Rosen. The comments of participants in the George Washington University Microeconomics Seminar are much appreciated.
} 


\section{Introduction}

Unemployment insurance replacement rates are systematically less than 100 percent worldwide. The distribution of $\mathrm{UI}$ replacement rates across highly industrialized economies from two standard sources--OECD and U.S. Social Security Administration--are graphed in Figure 1. The substantial difference between the two distributions no doubt reflects the difficulty of summarizing complex legislation in a single number. Nonetheless, the vast bulk of countries have replacement rates in the interval $50 \%$ to $79 \%$. In their classic study of the U.S. unemployment system, Haber and Murray (1966, p.173) noted the obscure origins of the 50 percent target still common in U.S. state systems: a "generally accepted concept was that the weekly benefit amount should be 50 percent of former wages. There is no record of why this percentage was chosen."

\section{$<$ figure 1>}

This incomplete income replacement in the face of job loss is often attributed to moral hazard problems, ${ }^{1}$ but could, in part or whole, reflect first-best benefit levels. Designers of job displacement insurance (unemployment insurance and severance pay) have devoted much attention to second-best considerations, including (i) the job search/offer acceptance distortions in unemployment insurance plans, ${ }^{2}$ and (ii) the layoff distortions in employer-financed severance plans (firing cost distortions). ${ }^{3}$ First-best UI benefits, when combined with the greater leisure that unemployment affords, may discourage the unemployed worker from seeking and accepting reemployment job offers--search moral hazard (SMH). Similarly, generous employerfinanced job displacement insurance, whether severance pay or UI, may induce excessive

\footnotetext{
1 "Over the years, a widely held view has formed that the weekly benefit amount should be high enough to sustain a worker and family without their having to resort to public welfare assistance, but that benefits should not be so high as to undermine the incentive to return to work. There has been little agreement on the specifics of how this principle should be implemented." O'Leary and Rubin (1997, p.164)

2 Holmlund (1998), Karni (1999), and Fredriksson and Holmlund (2006) provide excellent reviews. Paradigm theoretical studies of optimal unemployment insurance include Azariadis (1975), Baily (1977), Mortensen (1977), Shavell and Weiss (1979), and Hopenhayn and Nicolini (1997).

${ }^{3}$ See for example Emerson (1988) and Lazear (1990), and the reviews in Heckman and Pagés (2004), Holzmann, Pouget, Weber, and Vodopivec.(2012), and Parsons (2012a).
} 
retention in low demand periods, the "firing cost" problem, which is labeled here layoff moral hazard $(\mathrm{LMH})$.

Certainly search moral hazard is a serious practical concern in UI systems. ${ }^{4}$ If job search were time-intensive, unemployed workers might have no more "leisure" time than employed workers, but that is not the case. Krueger and Mueller (2008) provide a detailed description of time use of the employed and unemployed in the United States (and elsewhere) that illustrates how each spends time, Figure1, Panel A (weekdays) and Panel B (Weekend Days). ${ }^{5}$ The employed spend virtually no time on job search, which is not tautological given the high volume of voluntary separations (quits) that involve no unemployment spells. ${ }^{6}$ More surprising, the unemployed also devote little time to search, 40 minutes (of 1440 minutes) on weekdays and 9 minutes on weekends; unemployment is largely a waiting game. The time the unemployed "save" by not working is divided more or less equally among household production, socializing, and sleeping. ${ }^{7}$

$<$ figure 2>

Despite the empirical plausibility of moral hazard concerns, neither search moral hazard nor layoff (firing cost) moral hazard is a theoretical necessity in a first-best job separation insurance contract. ${ }^{8}$ Perhaps to emphasize nonstandard UI design concerns, Blanchard and Tirole (2008) exploit a utility function that induces neither in the first-best contract. ${ }^{9}$ First-best insurance requires the equalization of marginal utilities of consumption across states. If the greater leisure in the unemployed state dramatically depresses the marginal utility of consumption in that state, it is at least possible that equalizing the marginal utilities of

\footnotetext{
${ }^{4}$ The major focus here is in job displacement and long term unemployment--sufficiently long that benefit recipients can and do make long term psychological adjustments, Lindbeck (1995)--not in temporary layoffs or high turnover/short tenure jobs.

${ }^{5}$ Aguiar, Hurst, and Karabarbounis (2013) provide similar estimates.

${ }^{6}$ See Parsons (1991) among many others.

7 The employed reported spending 408 minutes on work on weekdays, and 112 on weekends.

${ }^{8}$ General reviews of the employment contracting literature include Parsons (1986), Malcomson (1999), and Salanié (2005).

9 Blanchard and Tirole (2008) employ a public choice model, but the formal difference is small. To highlight the underlying mechanism, the model is limited here to two labor demand states.
} 
consumption across states will reallocate sufficient consumption from the unemployed state to the employed state that the unemployed state will not be preferred.

The B\&T model has such a property--their basic utility structure has a familiar form, with monetized leisure summed with consumption in a single argument. This structure has the wellknown property that the equality of marginal utilities of consumption across states (the usual insurance optimality condition)--implies equality of utilities across states as well. ${ }^{10}$ Despite the additional, unmarketable leisure in the unemployed state, the unemployed worker has no incentive to disguise a reemployment wage offer under the first-best contract. The model is very special, however, and carries unattractive features, including linear indifference curves in consumption and leisure. ${ }^{11}$ It is natural to explore the conditions under which standard neoclassical utility functions in consumption and leisure yield first-best, moral-hazard-free contracts, as well as the richer policy question, what is the first-best unemployment insurance replacement rate? ${ }^{12}$

The paper proceeds as follows. A brief review of the optimal UI literature reveals a surprising variety of explicit utility models, though rarely the B\&T model, Section II. Section III returns briefly to the B\&T model. Job search moral hazard and layoff moral hazard are formally introduced and the absence of either in the B\&T model demonstrated. A general UI contracting model is developed in Section IV with neoclassical state utility functions-an increasing concave utility function in consumption and leisure. The conditions under which search MHF contracts arise are derived in Section $\mathrm{V}$. The analysis highlights a necessary condition for SMHF contracts--the cross-partial $u_{c \ell}$ must be negative, ${ }^{13}$ which insures that the optimal replacement

10 B\&T do develop a model in which unemployment generates anxiety (negative utility), breaking the link between the marginal utility of consumption and total utility. This of course leads the worker to be overeager to return to the job under first-best insurance contract.

${ }^{11}$ Leisure must be fixed in both the employed and unemployed state.

12 Consumption for short spells of unemployment may be maintained by savings and borrowing as well as unemployment insurance. The focus of this paper is on longer spells, when alternative methods of finance have plausibly been exhausted.

${ }^{13}$ Note that cardinality is required throughout this expected utility application. 
rate is less than 100 percent. For SMHF contracts to emerge, the cross-partial must be substantial (in absolute value). ${ }^{14}$ Sherwin Rosen $(1985$, p.1158) asserted that a first-best contract in a standard neoclassical utility structure will be SMHF only if leisure is an inferior good. The conditions under which a model is layoff moral hazard free (LMHF) are similar, if less rigid, Section VI.

There is substantial evidence that leisure is a normal good, and therefore not SMHF, so first-best contracts almost certainly trigger moral hazard distortions. ${ }^{15}$ Despite the implausibility of MHF first-best models, it remains useful to know the first-best UI replacement rate, if only to quantify the extent of moral hazard distortions in the current system. All specific utility functions in the optimal UI literature rule out SMHF outcomes, though many admit ideal UI replacement rates less than one, Section VII. The structural similarity of expected utility and time discounting raises the hope that the retirement literature may shed light on that question. ${ }^{16}$ The utility function implications of the intense effort to resolve the retirement consumption puzzle in the last two decades is reviewed in Section VIII. Section IX concludes.

\section{Utility Models in the Optimal UI Literature I}

A review of the utility function assumptions embedded in the optimal unemployment insurance literature reveals a surprising variety of state utility function assumptions. The early employment contracting papers, which did not focus on moral hazard issues, used the same monetized leisure model later adopted by B\&T. ${ }^{17}$ In his seminal employment contracting paper, for example, Azariadis (1975) employed the B\&T utility structure, ${ }^{18}$ but focused on wage stability

\footnotetext{
14 The conditions for layoff moral-hazard-free (LMHF) contracts are simpler, but similar. Parsons (2012a,b) provides a review of firing cost distortions in employment contracts.

${ }^{15}$ An inferior good requires a more complex form than the very regular functions used in the literature. An argument cannot be inferior at throughout,

${ }^{16}$ Chetty (2006) for example proposes such a connection.

17 When briefly considering divisible leisure and work hours. Azariadis adopted an additively separable form. See reviews of this early literature by Rosen (1985) and Parsons (1986).

18 Azariadis frames his discussion somewhat differently than B\&T and other employment contract scholars might today. He refers to "underemployment equilibria" to mean that the firm may undertake
} 
in the face of random shocks (with fixed work hours), and did not admit severance or unemployment insurance pay. In the absence of any sort of job displacement benefits, employers overemploy workers, which is to say they retain them in productivity states they would otherwise not. Baily (1974) also adopted this utility model in his intertemporal equivalent analysis, focusing his analysis on wage stability over time in the face of random shocks among retained workers (with fixed work hours), and treating unemployment benefits as government supplied and exogenous to the firm.

Other UI studies do not incorporate leisure into their models, presumably focusing on other facets of the optimal UI problem, e.g. Baily $(1977,1978)$, Flemming (1978), Acemoglu and Shimer (1999), Rogerson and Schindler (2002), Shimer and Werning (2008), and Pissarides (2010). Baily directly posited a reemployment duration function (the converse of unemployment duration), a positive function of money search costs and a negative function of UI benefits, and did not specify the underlying process that induced this gradient. The functional forms of the utility functions in the other studies varied. Acemoglu and Shimer, Pissarides, and, in one model, Shimer and Werning assumed only that the utility function be increasing and concave. Flemming and Acemoglu and Shimer employed the constant absolute risk aversion (CARA) model. Rogerson and Schindler and Shimer and Werning considered a constant relative risk aversion model (CRRA). But again none of these studies explicitly incorporate the key excess leisure assumption central to search moral hazard.

Among the studies that do incorporate leisure into the utility function, a state independent utility function additively separable in consumption (C) and leisure $(\ell)$ is common. Formally,

$$
U(C, \ell)=u(C)+v(\ell)
$$

layoffs; the complement outcome is retention in the job ("job protection" in B\&T's terminology) or guaranteed employment in the model to follow. 
with $u(\cdot)$ strictly concave and $v(\cdot)$ concave..$^{19}$ The additively separable utility model is occasionally framed with search effort (negative leisure) as an argument in addition to consumption, but the structural implications are equivalent. Shavell and Weiss (1979) for example frame the unemployed worker's decision within an additively separable state utility function in consumption and search effort (e):

$$
U(C, e)=u(c)-e
$$

with search time positively affecting the probability of securing the next job. ${ }^{20}$ They famously demonstrated that optimal UI benefits should decrease in duration of employment. ${ }^{21}$ Similarly Hopenhayn and Nicolini (1997) employ the additively separable model, focusing on search time among the unemployed. They note that:

"...we have not considered explicitly the disutility of effort when the agent is employed. Though this can affect the quantitative results, it is a constant term in the utility of an employed worker and has not consequence on the qualitative properties of the optimal contract..." (p. 416).

Both Shavell and Weiss and Hopenhayn and Nicolini adopt power functions for the separate consumption and leisure (search) functions. ${ }^{22}$

Common in the macro labor literature are constant relative risk aversion (CRRA) and constant absolute risk aversion (CARA) assumptions, whether, for example, as individual, additively separable consumption and leisure functions--Heathcote, Storesletten and Violante (2014) and Chetty (2008) in simulations_or as a basic structure within which a composite consumption and leisure good is embedded. Hansen and imrohoroglu (1992) for example adopt a CRRA model with an embedded Cobb-Douglas composite consumption and leisure

\footnotetext{
19 Leisure has an upper bound, the amount of total time available (or one if interpreted as a share of time), which we will generally ignore.

${ }^{20}$ This converts to a standard consumption leisure model with $e=1-\ell$ in the unemployed state and $e=$ 1 in the employed state.

21 The result holds for a model that does not allow wealth, saving, or borrowing.

22 This model is much the same as that adopted by MaCurdy (1981) in a life cycle context.
} 
good $^{23}$ as do Acemoglu and Shimer (2000). Attanasio and Weber $(1993,1995)^{24}$ use a variant on the CRRA model with embedded composite good of the form:

$$
U=\frac{1}{1-\gamma}\left[e^{\delta \ell} C\right]^{1-\gamma} \text { if } \gamma \neq 1 \text { and } 0<\delta<1
$$

The constant absolute risk aversion (CARA) model is also found in the literature, especially when saving is admitted in the model. The analytical advantage of having desired savings not change with wealth apparently outweighs the model's implausibility, Flemming (1978) and Shimer and Werning (2008). If a Cobb-Douglas structure in consumption and leisure is embedded in the CARA model, the model becomes:

$$
U=-\frac{1}{\varepsilon} e^{-\varepsilon C^{\alpha} \ell \beta}, \varepsilon>0 \text { and } 0<\alpha, \beta<1
$$

We will return to the moral hazard implications of these functional forms after considering the standard neoclassical utility model, within which all are embedded (the B\&T model excepted). Before doing that, however, it will be helpful to sketch out formally the proof of B\&T's claim that the monetized leisure model is both search and layoff moral hazard free.

\section{The Blanchard and Tirole Model}

In the familiar employment contracting environment, assume that a worker in a competitive market accepts an employment contract before learning whether his productivity in the firm is high or low. ${ }^{25}$ Depending on the size of the demand shock and the feasibility of separation benefits, the worker and firm may commit to retain the worker in the bad state (guaranteed employment) or accept layoff in the bad state with an appropriate separation package. The separation package might offer some combination of severance pay (lump-sum payment at separation) and unemployment benefits (payments conditioned on not being

\footnotetext{
${ }^{23}$ Mankiw, Rotemberg, and Summers (1985) consider a CRRA model with a composite CES function of consumption and leisure.

${ }^{24}$ Variant with $Z=\ell$.

${ }^{25}$ Blanchard and Tirole frame the issue in similar, if somewhat less familiar, public choice structure.
} 
reemployment), although the B\&T model does not admit reemployment, so the distinction is irrelevant here.

The contracting firm is risk neutral, with a utility function linear in expected profits $E(\pi)$, and finds it profitable to provide the risk averse worker with some form of earnings insurance. Depending on conditions, especially the severity of the fluctuation in firm productivity across demand states, the firm will offer one of two types of contracts:

- GUARANTEED EMPLOYMENT (GE), or

- LAYOFF WITH SEPARATION BENEFITS (LAYOFF).

The early literature, prominently Azariadis (1975), focused on "excess" GE contracts as an alternative to separation benefits. If however demand fluctuations are sufficiently severe, layoff contracts will dominate, even in second-best circumstances.

Formally the value of a worker's product within the firm is a random variable which depends on the state of product demand. In the simplest case there are two mutually exclusive and exhaustive demand states, $S_{i}, i=1,2$, with a probability $\rho$ that $S_{1}$ will occur. ${ }^{26}$ Label $S_{1}$ and $\mathrm{S}_{2}$ the high-demand (good) state and low-demand (bad) state respectively. Assume that the firm's fulltime work productivity is $v$ in the high demand state and $\theta v$ in the low demand state, $0 \leq \theta<1$

The individual and the firm contract over whether the individual works in the low demand state or is laid off. Workers who accept GE contracts will be retained by the firm in both the good and the bad state, though theoretically their wages may vary across states. ${ }^{27}$ The layoff contract workers will end up in one of two circumstances: (1) retained by the contracting firm at a contract wage, or (2) laid off with no job offer. The LAYOFF contract requires specification of

\footnotetext{
${ }^{26}$ Azariadis (1975) considers a set of productivity outcomes, Rosen (1985) and B\&T (2008) a continuum, but these do not affect the basic structure of the insurance schemes and add substantially to the complexity of the model. The firm size issue embedded in Azariadis and Rosen is also ignored here.

27 Employing the same utility model (with fixed hours) as B\&T, Azariadis (1975) and Baily (1974) demonstrated that the firm will offer the same wage in both states.
} 
earnings and work hours in the high demand state and the separation package $(B)$ in the low, where $B$ denotes unemployment insurance.

The precise structure of the utility function is critical. The basic Blanchard and Tirole utility structure has the form:

$$
u(C+\mu \hat{\ell})
$$

with $u(\cdot)$ an increasing concave function and $\mu$ and $\hat{\ell}$ positive constants. Presumably the potential unemployed state offers greater leisure than employment, $\hat{\ell}_{2}>\hat{\ell}_{1}$, and in fact B\&T consider only $\Delta \widehat{\ell}=\widehat{\ell}_{2}-\widehat{\ell}_{1}>0$, the incremental leisure available to the unemployed worker, suppressing the common base $\hat{\ell}_{1}$. B\&T demonstrate that this model is both search and layoff moral-hazard-free, and it is instructive to review these claims.

The T\&P model is developed formally in Appendix a, but it is clear that the first-best insurance plan would not induce the unemployed worker with a B\&T utility function to conceal (or discourage) job offers. In the B\&T utility model, the usual equality of marginal utilities with complete, costless insurance implies that utility is equal across states as well. The retained (reemployed) worker has the same utility as the unemployed worker and has no incentive to conceal a job offer. ${ }^{28}$

Layoff moral hazard is a financial calculation of the firm. Are separation payouts sufficiently large that the firm would not report that the bad state had occurred, instead preferring to pay the worker "good state" wages while receiving the diminished product rather than disburse separation benefits? Put otherwise, will these benefits, if self-financed by the firm, induce strategic worker retention in the bad (layoff) state?

The answer is no for the B\&T utility function, because the worker and firm will negotiate a GE contract in some economic circumstances, and these circumstances are precisely those

\footnotetext{
${ }^{28}$ See Appendix 1 for the formal model.
} 
that would otherwise induce layoff moral hazard if the worker were laid off. The key intuition here is that the same forces that would tempt the firm to disguise the bad state and continue employing the worker-including relatively high productivity in the bad state-are the same forces that would have the two parties negotiate the GE contract in the first place.

Formally, if the layoff contract wage of retained workers is $W$, then the first-best contract will be LMHF as long as

$$
W-\theta v \geq B
$$

the net cost of retention equals or exceeds the cost of separation benefits. Does this condition hold in the first-best contract? The B\&T first-best contract has marginal utility and total utility the same in both states, employed and unemployed, so that:

$$
W=B+\mu \Delta \hat{\ell}
$$

Equations (2) and (3) together imply a LMHF condition of:

$$
\mu \Delta \hat{\ell} \geq \theta v
$$

But this condition always holds if the layoff contract is chosen. Expected composite consumption under a zero profit constraint will be equal across states, $\rho v+(1-\rho) \theta v$ in the GE contract and $v+(1-\rho) \mu \Delta \hat{\ell}$ in the layoff contract. In the full insurance environment the layoff contract will be chosen if expected consumption is higher:

$$
\begin{aligned}
& \rho v+(1-\rho) \mu \Delta \hat{\ell} \geq \rho v+(1-\rho) \theta v, \text { or } \\
& \mu \Delta \hat{\ell} \geq \theta v .
\end{aligned}
$$

Comparing this with the LMHF requirement, Equation (4), layoff contracts will only be chosen (over GE contracts) when they are LMHF. 


\section{First-Best Employment Contracts with Leisure Choice}

Under what conditions would a standard neoclassical utility function yield MHF FB contracts $?^{29}$ The worker is assumed to maximize expected utility with state independent utility functions in consumption and leisure of the general form,

$$
U=u(C, \ell) \quad 0 \leq \ell \leq 1
$$

which is an increasing concave function in $\mathrm{C}$ and $\ell$. The unemployed worker has excess leisure that he cannot sell in the market, and he can consume only what is provided in his unemployment insurance benefits.

Assume that productivity is linear in work hours in all employment states: high and low demand in the GE contract and high demand in the layoff contract. Under the GE contract, productivities in the high and low demand states are respectively:

$$
\begin{array}{ll}
v_{1}^{*}=v h_{1}^{*}=v\left(1-\ell_{1}^{*}\right), & \text { and } \\
v_{2}^{*}=v h_{2}^{*}=\theta v\left(1-\ell_{2}^{*}\right), & 0 \leq \theta<1,
\end{array}
$$

where the asterisk denotes GE values. With the absence of the asterisk, the linear model, Equation 8a, applies to retained workers under the layoff contract as well.

GE Contract. With flexible work hours, wages (consumption) need not be equal across states in the GE model because leisure hours may vary, which will in general have consequences for optimal consumption. Consider the first-best GE contract formally. ${ }^{30}$ Forming the Lagrangian in consumption:

\footnotetext{
29 Heckman (1974) is the classic statement of the neoclassical model of nonseparable consumption and leisure over the life cycle, which extends immediately to optimal insurance strategies.

30 Moral hazard problems could arise in this case. For example it is possible that the firm might falsely announce that the bad state had occurred if work hours are higher and earnings lower in that state, but this possibility will be ignored here.
} 


$$
\begin{aligned}
\mathcal{L}= & \rho u\left(C_{1}^{*}, \ell_{1}^{*}\right)+(1-\rho) u\left(C_{2}^{*}, \ell_{2}^{*}\right) \\
& -\lambda\left(\rho C_{1}^{*}+(1-\rho) C_{2}^{*}-\rho v\left(1-\ell_{1}^{*}\right)-(1-\rho) \theta v\left(1-\ell_{2}^{*}\right)-I_{0}\right),
\end{aligned}
$$

where $I_{0}$ denotes non-earned income and asterisks denote the GE contract. The first order conditions simplify to:

$$
\begin{aligned}
& u_{C}\left(C_{1}^{*}, \ell_{1}^{*}\right)-\lambda=0, \\
& u_{\ell}\left(C_{1}^{*}, \ell_{1}^{*}\right)-\lambda v=0, \\
& u_{C}\left(C_{2}^{*}, \ell_{2}^{*}\right)-\lambda=0, \\
& u_{\ell}\left(C_{2}^{*}, \ell_{2}^{*}\right)-\lambda \theta v=0, \quad \text { and } \\
& \rho C_{1}^{*}+(1-\rho) C_{2}^{*}-\rho v\left(1-\ell_{1}^{*}\right)-(1-\rho) \theta v\left(1-\ell_{2}^{*}\right)-I_{0}=0 .
\end{aligned}
$$

Clearly the marginal utility of consumption must be equal across states (Equations 10a and 10c), but consumption need not be, because the ratio of leisure marginal utilities in the GE contract should equal the ratio of productivity in the two states.

Work hours are flexible, and one could expect the worker to work more in the high demand state, less in the low demand state. ${ }^{31}$ In this discrete two state structure, income effects of $\theta$ grow quite large as the fraction of time spent in the low demand state grows, and comparative static results are ambiguous. As $\rho \rightarrow 1$, however, the income effect vanishes, and it is easily proven that indeed $\frac{d \ell_{2}^{*}}{d \theta}<0$. See Appendix 2 .

Layoff Model. The layoff model can be specified in terms of three choice variables, either consumption (two states) and leisure (one) $\left(C_{1}, \ell_{1} ; C_{2}\right)$ or in the underlying contract parameters $\left(W, \ell_{1} ; B\right)$ with, as before, $W$ denoting earnings in the retained state and $B$

31 This echoes a familiar result in the lifecycle labor supply literature. 
(separation benefits) if laid off, and $\ell_{1}$ in the second case is the complement of work hours. Forming the Lagrangian in consumption:

$$
\mathcal{L}=\rho u\left(C_{1}, \ell_{1}\right)+(1-\rho) u\left(C_{2}, \hat{\ell}_{2}\right)-\lambda\left(\rho C_{1}+(1-\rho) C_{2}-\rho v\left(1-\ell_{1}\right)-I_{0}\right)
$$

where $\hat{\ell}_{2}$ denotes fixed, presumably maximum, leisure in the unemployed state.

The first order conditions simplify to:

$$
\begin{aligned}
& u_{C}\left(C_{1}, \ell_{1}\right)-\lambda=0 \\
& u_{\ell}\left(C_{1}, \ell_{1}\right)-\lambda v=0 \\
& u_{C}\left(C_{2}, \hat{\ell}_{2}\right)-\lambda=0 \\
& -\left(\rho C_{1}+(1-\rho) C_{2}-\rho v\left(1-\ell_{1}\right)-I_{0}\right)=0
\end{aligned}
$$

Some features of the first-best contract are obvious, including the equality of marginal utilities of consumption across states (12a and 12c). Again this will not in general lead to the equality of consumption across states because leisure varies.

It is straightforward to derive the impact of a bit of additional leisure in the unemployed state $\left(\hat{\ell}_{2}\right)$ on contractual consumption in the unemployed state and consumption and leisure (or work hours) in the employed state, Appendix 3. Consider the impact of an increment of unemployed leisure on the consumption of the unemployed $\left(C_{2}\right)$, a pivotal process in the full insurance story to follow. The usual comparative statics manipulations reveal that:

$\frac{d C_{2}}{d \hat{\ell}_{2}}=-\rho u_{C \ell}\left(C_{2}, \hat{\ell}_{2}\right) \frac{1}{\Delta}\left[2 v u_{C \ell}\left(C_{1}, \ell_{1}\right)-u_{\ell \ell}\left(C_{1}, \ell_{1}\right)-v^{2} u_{C C}\left(C_{1}, \ell_{1}\right)\right]$

with the last term in brackets positive and $\Delta<0, \Delta$ defined in Appendix 3. Reasonably, $\frac{d C_{2}}{d \hat{\ell}_{2}}$ is of the same sign as $u_{C \ell}\left(C_{2}, \hat{\ell}_{2}\right)$; the contract calls for greater consumption in the unemployed state with greater unmarketable leisure if and only if the marginal utility of consumption increases in leisure. 
The full mechanics of this expected utility model are worth reprising. The additional unmarketable leisure in the unemployed state alters the marginal utility of consumption, which in turn triggers a rebalancing of resources across states to again equalize marginal utilities of consumption across states. If the state utility function is additively separable $\left(u_{C \ell}=0\right)$, additional leisure does not alter the worker's optimal distribution of consumption across states, behavior in the employed state is not affected, and total utility in the unemployed state will be higher with the additional leisure. If $u_{C \ell}<0$, an increment to unemployed leisure will depress the marginal utility of the consumption of the unemployed, inducing a shift of resources toward the employed outcome in which the marginal utility of consumption is higher. The shift of consumption to the employed state must be very large if the increment to (non-marketable) leisure in the unemployed states is to be offset in the insurance contract.

For example, comparative statics of the first-best contract (Appendix 3) reveal that:

$$
\frac{d C_{1}}{d \hat{\ell}_{2}}=\frac{1}{\Delta}(1-\rho) u_{C \ell}\left(C_{2}, \hat{\ell}_{2}\right)\left[v u_{C \ell}\left(C_{1}, \ell_{1}\right)-u_{\ell \ell}\left(C_{1}, \ell_{1}\right)\right]
$$

The interconnections become clear when combining Equations (13) and (14):

$$
\frac{d C_{1}}{d \hat{\ell}_{2}}=-\frac{(1-\rho)}{\rho}\left[\frac{v u_{C \ell}\left(C_{1}, \ell_{1}\right)-u_{\ell \ell}\left(C_{1}, \ell_{1}\right)}{2 v u_{C \ell}\left(C_{1}, \ell_{1}\right)-u_{\ell \ell}\left(C_{1}, \ell_{1}\right)-v^{2} u_{C C}\left(C_{1}, \ell_{1}\right)}\right] \frac{d C_{2}}{d \hat{\ell}_{2}}
$$

The numerator of the term in brackets is proportional to the income effect on $C_{1}$ (see again Appendix 3 below). If positive, consumption is a normal good and $\frac{d C_{1}}{d \hat{\ell}_{2}}$ will be opposite in sign to $\frac{d C_{2}}{d \hat{\ell}_{2}}$. Similarly,

$$
\frac{d \ell_{1}}{d \hat{\ell}_{2}}=\frac{1}{\Delta}(1-\rho) u_{C \ell}\left(C_{2}, \hat{\ell}_{2}\right)\left[u_{C \ell}\left(C_{1}, \ell_{1}\right)-v u_{C C}\left(C_{1}, \ell_{1}\right)\right]
$$

and

$$
\frac{d \ell_{1}}{d \hat{\ell}_{2}}=-\frac{(1-\rho)}{\rho} \frac{\left[u_{C \ell}\left(C_{1}, \ell_{1}\right)-v u_{C C}\left(C_{1}, \ell_{1}\right)\right]}{\left[2 v u_{C \ell}\left(C_{1}, \ell_{1}\right)-u_{\ell \ell}\left(C_{1}, \ell_{1}\right)-v^{2} u_{C C}\left(C_{1}, \ell_{1}\right)\right]} \frac{d C_{2}}{d \hat{\ell}_{2}}
$$


This has the same interpretation as the change in employed consumption, with the change in employed leisure opposite in sign if leisure is a normal good, and the same in sign if leisure is an inferior good.

Note the impact of the likelihood of retaining the worker in employment $(\rho)$ in this scenario. In the limit, as $\rho \rightarrow 1$ and very few are unemployed, the effect of a change in $C_{2}$ on consumption or leisure in the employed state approaches zero. The marginal utility of consumption of the employed will be unaffected by the circumstances of the few unemployed: basically a Frisch (marginal utility of consumption constant) labor supply circumstance. Conversely if $\rho \rightarrow 0$ the marginal utility of consumption will be set in the unemployed state, and will potentially be sensitive to variations in leisure in the unemployed state.

\section{Job Search Moral Hazard}

Consider search (job acceptance) moral hazard in this general model. Under what conditions will a laid off worker not reject a reemployment offer, foregoing the leisure $\left(\hat{\ell}_{2}\right)$ and unemployment benefits $(B)$ that the contract provides? The worker's economic decision rule is straightforward: reveal (and accept) a job offer if utility in the retained (reemployed) state (1) is at least as great as utility in the unemployed state (3):

$$
\delta \equiv u\left(C_{1}, \ell_{1}\right)-u\left(C_{2}, \hat{\ell}_{2}\right) \geq 0
$$

Denote this the Search Moral-Hazard-Free (SMHF) condition. Variation in unemployed leisure will induce the following change in the probability the worker will accept an offered job:

$$
\frac{d \delta}{d \hat{\ell}_{2}}=u_{c}\left(C_{1}, \ell_{1}\right) \frac{d C_{1}}{d \hat{\ell}_{2}}+u_{\ell}\left(C_{1}, \ell_{1}\right) \frac{d \ell_{1}}{d \hat{\ell}_{2}}-u_{c}\left(C_{2}, \hat{\ell}_{2}\right) \frac{d C_{2}}{d \hat{\ell}_{2}}-u_{\ell}\left(C_{2}, \hat{\ell}_{2}\right),
$$


where the subscripts on the utility function denote the usual partial derivatives. An increment to unemployed leisure will not reduce the unemployed worker's offer-acceptance likelihood as long as $\frac{d \delta}{d \hat{\ell}_{2}} \geq 0$

Recalling the comparative statics of the first-best solution, Equations (13)-(15), Equation (17) simplifies to

$$
\frac{d \delta}{d \hat{\ell}_{2}}=-\left[\frac{(1-\rho)}{\rho} u_{c}\left(C_{1}, \ell_{1}\right)+u_{c}\left(C_{2}, \hat{\ell}_{2}\right)\right] \frac{d C_{2}}{d \hat{\ell}_{2}}-u_{\ell}\left(C_{2}, \hat{\ell}_{2}\right)
$$

For a change in leisure in the unemployed state (2) to induce a nonnegative change in the relative advantage of being reemployed $\left(\frac{d \delta}{d \hat{\ell}_{2}}>0\right)$, it is necessary that $\frac{d C_{2}}{d \hat{\ell}_{2}}<0$, which in turn requires that $u_{c \ell}<0$.

Proposition 1: for greater unmarketable leisure in the unemployed state to have no search moral hazard effect in the first-best contract it is necessary that consumption and leisure be substitutes $\left(u_{c \ell}<0\right)$.

Clearly that is not sufficient to insure that an increment to unemployed leisure will not make the unemployed state more attractive, because an increment of leisure in the unemployed state has a direct positive utility effect on unemployment. The monetary resource shift to the employed state must be large to offset that effect. In his analysis of the interplay of leisure and consumption in (labor) insurance contracts, Sherwin Rosen noted a simple test of SMHF properties (in the jargon used here)--leisure must be an inferior good in the state utility function. ${ }^{32}$

A complete insurance contract makes a worker who has "suffered" an adverse draw of an insurable risk better off ex post than a worker who draws a more favorable value except when income effects are negative. Contracts underinsure ex post utility levels only when leisure is an inferior good. Rosen (1985, p.1158)

Consider then the conditions which the employment contract here would be MHF. Recalling the usual comparative statics of this system, Equations (13)-(15), as well as the fact that

${ }^{32}$ At the MHF boundary, independent of income. 
$u_{C}\left(C_{1}, \ell_{1}\right)=u_{C}\left(C_{2}, \hat{\ell}_{2}\right)$ from the first order conditions, we find that an increment to unemployed leisure will not favor the unemployed state as long as

$$
\begin{gathered}
\frac{d \delta}{d \hat{\ell}_{2}}=\frac{1}{\Delta} u_{C}\left(C_{2}, \hat{\ell}_{2}\right) u_{C \ell}\left(C_{2}, \hat{\ell}_{2}\right)\left\{u_{\ell \ell}\left(C_{1}, \ell_{1}\right)+v^{2} u_{C C}\left(C_{1}, \ell_{1}\right)-2 v u_{C \ell}\left(C_{1}, \ell_{1}\right)\right\} \\
-u_{\ell}\left(C_{2}, \hat{\ell}_{2}\right) \geq 0
\end{gathered}
$$

Rosen analyzed a model with a continuum of demand states, so that the lambda constant demand functions could be used for a shift in leisure in any state. The Rosen proposition emerges here under the assumption that the bulk of the population is employed $(\rho \rightarrow 1)$. In that case:

$$
\lim _{\rho \rightarrow 1} \frac{d \delta}{d \hat{\ell}_{2}}=u_{C}\left(C_{2}, \hat{\ell}_{2}\right) \frac{u_{C \ell}\left(C_{2}, \hat{\ell}_{2}\right)}{u_{C C}\left(C_{2}, \hat{\ell}_{2}\right)}-u_{\ell}\left(C_{2}, \hat{\ell}_{2}\right) \geq 0
$$

The inequality can be otherwise expressed as:

$$
\frac{u_{C}\left(C_{2}, \hat{\ell}_{2}\right)}{u_{C C}\left(C_{2}, \hat{\ell}_{2}\right)}\left[u_{C \ell}\left(C_{2}, \hat{\ell}_{2}\right)-\frac{u_{\ell}\left(C_{2}, \hat{\ell}_{2}\right)}{u_{C}\left(C_{2}, \hat{\ell}_{2}\right)} u_{C C}\left(C_{2}, \hat{\ell}_{2}\right)\right] \geq 0
$$

with the term in brackets the numerator of the familiar income effect on leisure. This inequality holds if leisure is an inferior good (or independent of income at the boundary).

Proposition 2: if the unemployment risk is sufficiently small, greater unmarketable leisure in the unemployed state will have no effect on search moral hazard as long as leisure is an inferior good in the state utility function.

Informally the Rosen proposition emerges from the recognition that the small number of unemployed workers are going to have little financial impact on the vast number of reemployed workers. Given an additional unit of leisure to the unemployed will in the first instance reduce their marginal utility of consumption if $u_{C \ell}<0$, which will in turn induce a change in planned consumption in the first-best contract. Though it will have no demonstrable effect on consumption of the employed because of the relative numbers of each group, it will increase the marginal utility of consumption of the unemployed. In a full insurance world this consumption 
reallocation will continue until the marginal utility of consumption is equal across the two outcomes (until the marginal utility of consumption returns to initial levels). The impact on the relative utilities of the two groups depends on how much consumption is transferred to the employed before the original equality of marginal utilities of consumption is reached. It is easily shown that the inferior leisure condition emerges in this case.

Such a simple rule does not arise if the likelihood of unemployment is not small. ${ }^{33}$ Consider the slightly more complicated story in that case. The initial impact would be the same. An increment to leisure in the unemployed state would induce a drop in the marginal utility of consumption $\left(u_{C \ell}<0\right)$, creating a need to reallocate consumption toward the employed in the insurance contract. As consumption is shifted from the unemployed to the employed to reestablish the usual insurance condition, the impact on the consumption of the employed will now be measurably affected and the insurance equilibrium will be reestablished with the marginal utility of consumption lower than the original level though higher than the initial decline. The usual marginal condition between leisure and consumption in the employed period means that the shape of the indirect utility function is crucial in determining the marginal utility of the unemployed, making the relative utilities of the two states hard to characterize at the insurance equilibrium (in marginal utilities of consumption).

\section{Utility Models in the Optimal UI Literature 2}

With the negative cross derivative requirement and the more stringent "leisure as an inferior good" test in mind, consider the specific functional form assumptions for utility used in the optimal unemployment insurance literature (Section II). Which admit the possibility of MHF FB contracts? Structurally we want to determine (i) which utility assumptions admit the possibility that that cross partial of consumption and leisure on utility is negative, and (ii) which

\footnotetext{
${ }^{33}$ From Equation (13) it would appear that a reduction in $\rho$ under these conditions (leisure as an inferior good) will lead to a yet greater increase in transfers to consumption of the employed under first-best insurance contract. As it happens, $\rho$ is also found in $\Delta$ in the denominator (see Appendix 3 ).
} 
admit the possibility of leisure as an inferior good, insuring MHF first-best contracts in some circumstances.

The monetized leisure model, at least in its simplest form, implies MHF FB insurance, but requires that leisure be fixed, not a choice variable, which is always a limitation in a work/leisure study. Among those studies which include leisure as well as consumption as choice variables, the simple Cobb-Douglas model in consumption and leisure (with positive exponents) fails on all counts. The cross derivative of the utility function is positive and, a fortiori, leisure is a normal good. Moral hazard will arise in this structure.

The common additively separable utility function of course implies $u_{C \ell}=0$, which guarantees search moral hazard problems. Leisure has no impact on the marginal utility of (generalized) consumption, there is no transfer of consumption resources from the unemployed state to the employed state, and utility will be higher in unemployment. The equality of marginal utilities of consumption across outcomes—retained or laid off/unemployed-implies equal consumption, not equal utilities. With equal consumption in all outcomes and more leisure in one (unemployment), search moral hazard is certain. In the additively separable model, key $\mathrm{MH}$ properties do not depend on specific functional forms for the individual elements. Individual additively separable CRRA models for consumption and leisure, Heathcote, Storesletten and Violante (2014) and Chetty (2008) in simulations are not SMHF.

More interesting are the CRRA and CARA models with embedded consumption-leisure elements. The CRRA model with an embedded Cobb-Douglas composite consumption and leisure good--Hansen and imrohoroglu (1992) and Acemoglu and Shimer (2000)-is more 
flexible than the additively separable form, ${ }^{34}$ and admits a wide range of possible values for $u_{C \ell}$ and, in the limit, the possibility of moral hazard free contracts. ${ }^{35}$ The model:

$$
\begin{aligned}
& U=\frac{1}{1-\gamma}\left[C^{\alpha} \ell^{\beta}\right]^{1-\gamma} \quad \text { if } \gamma \neq 1 \text { and } \alpha, \beta>0 \\
& U=\alpha \ln C+\beta \ln (\ell) \quad \text { if } \gamma=1,
\end{aligned}
$$

where again $\gamma, \alpha, \beta>0 .{ }^{36}$ As Hansen and Imrohoroglu note:

This utility function, which is common in the macroeconomics literature, displays constant relative risk aversion (constant intertemporal elasticity of substitution) and an intratemporal elasticity of substitution between consumption and leisure equal to one. Hansen and Imrohoroglu (1992. 122).

It is transparent that $U_{C \ell}=0$ for the semilog form, Equation (22b), which insures search moral hazard, though not necessarily layoff moral hazard. The general power function with the embedded Cobb-Douglas $(\gamma \neq 1)$ is more interesting, with

$$
U_{C \ell}=-(\gamma-1) \frac{\alpha \beta}{C^{1+\alpha(\gamma-1)} \ell^{1+\beta(\gamma-1)}}
$$

The sign of $U_{C \ell}$ depends in a simple way on the magnitude of $\mathrm{y}$ : it is positive if $\gamma<1$, zero if $\gamma=1$, and negative if $\gamma>1$. Macro-labor economists typically assume $\mathrm{y}>1$, which implies that MHF utility functions are at least possible. ${ }^{37}$

The issue then is whether the cross-derivative is both negative and sufficiently large in absolute value that the additional leisure in unemployment will induce a shift in resources from the unemployed state to the employed state such that the unemployed will prefer the reemployed state. The intrastate trade-off between consumption and leisure is wholly

\footnotetext{
${ }^{34}$ Mankiw, Rotemberg, and Summers (1985) consider a CRRA model with a composite CES function of consumption and leisure.

${ }_{35}$ Acemoglu and Shimer (2000) assume parameter values for the utility function with the property that $u_{C \ell}<0$, although not so large in absolute value as to imply FB MHF contracts.

${ }^{36}$ Acemoglu and Shimer (2000) use this assumption in their UI simulations. In the notation used here, they assume $\gamma=4, \alpha=1$, and $\beta=0.1667$ which implies a reduction in consumption in unemployment in the first-best contract, but not sufficient to imply a moral-hazard-free first-best contract.

${ }^{37}$ See however Chetty (2006).
} 
determined by the composite form, in this case the Cobb-Douglas element, so leisure is a normal good, and the form does not admit a SMHF outcome. In the CRRA(CD) model, the effect of an increment to unemployed leisure on the SMHF criteria $\left(\frac{d \delta}{d \widehat{\ell}_{2}}\right)$ will be negative, although the effect on SMH diminishes under the optimal contract as the worker becomes more risk averse.

Attanasio and Weber $(1993,1995)^{38}$ use a variant on the CRRA(CD) model, one of the form:

$$
U=\frac{1}{1-\gamma}\left[e^{\delta \ell} C\right]^{1-\gamma} \text { if } \gamma \neq 1 \text { and } 0<\delta<1
$$

Although it might not be immediately obvious, this structure has properties similar to the familiar quasi-linear model, with all income directed to leisure after a certain consumption level is reached. Although an unattractive property, the model presumably has offsetting analytical convenience properties. In this application, $d \widehat{\ell}_{2}$ would simply be absorbed as additional leisure in the low demand state.

The constant absolute risk aversion (CARA) model is also found in the literature, Flemming (1978) and Shimer and Werning (2008). If a Cobb-Douglas structure in consumption and leisure is embedded in the CARA model, the model becomes:

$$
U=-\frac{1}{\varepsilon} e^{-\varepsilon C^{\alpha} \ell^{\beta}}, \varepsilon>0 \text { and } 0<\alpha, \beta<1
$$

Its characteristics are similar to those of CRRA.

Apparently none of the specific utility models used to model optimal UI admits SMHF. However, the familiar CRRA and CARA models with embedded Cobb-Douglas utility functions imply first-best replacement rates less than $100 \%$ if the risk aversion parameter exceeds a critical amount $(\gamma>1$.).

\footnotetext{
${ }^{38}$ Variant with $Z=\ell$.
} 


\section{Layoff Moral Hazard (Firing Costs)}

Layoff moral hazard may not be binding for two distinct reasons: (1) the obvious--that expected expenditures on benefits in the bad state are small, or (2) the less obvious--that situations in which layoff moral hazard would arise are the same conditions that induce the contracting parties to avoid layoffs altogether (GE contracts). The second is prominent in the B\&T treatment, Section III above.

Consider the first reason. The firm negotiates with the worker a first-best contract that involves earnings and work effort if retained and, as insurer, severance pay and unemployment insurance benefits if laid off. Because the firm is the only agent to observe directly the demand state, it may have an incentive to disguise the bad state in order to avoid separation benefit payouts. The employer-insurer's problem is not as simple as that of standard insurers because the employer presumably must act as if the good state has emerged and pay the retained worker the good state wage and work hours (leisure).

Formally LMHF requires that the net cost of retaining a worker in the low demand state $\left[W-\theta v\left(1-\ell_{1}\right]\right.$ be equal or greater than the expected payouts to laid-off workers $B$ :

$$
\begin{aligned}
& \Omega=W-\theta v\left(1-\ell_{1}\right)-B \geq 0, \text { or in consumption terms, } \\
& \Omega=C_{1}-C_{2}-\theta v\left(1-\ell_{1}\right) \geq 0
\end{aligned}
$$

where $0 \leq \theta<1$ is the low demand state productivity parameter in the contracting firm. In consumption terms, this reduces to the differential:

$$
\frac{d \Omega}{d \hat{\ell}_{2}}=\frac{d C_{1}}{d \hat{\ell}_{2}}+\theta v \frac{d \ell_{1}}{d \hat{\ell}_{2}}-\frac{d C_{2}}{d \hat{\ell}_{2}} \geq 0
$$

The parallels and differences with the differential form of the SMHF requirement, reproduced here,

$$
\frac{d \delta}{d \hat{\ell}_{2}}=u_{c}\left(C_{1}, \ell_{1}\right) \frac{d C_{1}}{d \hat{\ell}_{2}}+u_{\ell}\left(C_{1}, \ell_{1}\right) \frac{d \ell_{1}}{d \hat{\ell}_{2}}-u_{c}\left(C_{2}, \hat{\ell}_{2}\right) \frac{d C_{2}}{d \hat{\ell}_{2}}-u_{\ell}\left(C_{2}, \hat{\ell}_{2}\right),
$$


make it unsurprising that the two often move in the same direction, although additional leisure in the unemployed state has no direct implications for the budget constraint.

As the discussion of the LMHF property of the B\&T model makes clear, a second element is also important, the conditions under which the GE contract will dominate and LMH deviations become moot. The GE contract will dominate only if maximum expected utility under that contract exceeds the maximum expected utility under the LO contract. The GE contract will be preferred if:

$$
\tau=E U_{G E}-E U_{L O}>0
$$

where: $E U_{G E}=\rho u\left(C_{1}^{*}, \ell_{1}^{*}\right)+(1-\rho) u\left(C_{2}^{*}, \ell_{2}^{*}\right)$, and $E U_{L O}=\rho u\left(C_{1}, \ell_{1}\right)+(1-\rho) u\left(C_{2}, \hat{\ell}_{2}\right)$ and the choice variables are evaluated at their optimal values. It is transparent that $\frac{d \tau}{d \hat{\ell}_{2}}<0$, because leisure is a good which increases the worker's expected utility only if the worker elects the layoff contract. Conversely an increase in worker productivity in the bad state only has positive expected utility effects if the worker elects the GE contract, so $\frac{d \tau}{d \theta}>0$.

\section{First-Best Consumption: The Retirement Evidence ${ }^{39}$}

Whether first-best contracts are moral-hazard-free depends on the worker's preference function and is ultimately an empirical question. Labor supply responses have been subject to intense empirical investigation, but may provide little direct insight into the sign and magnitude of the cross derivative of consumption and leisure on utility, a key utility characteristic. Keene and Rogerson (2012), for example, argue that labor supply studies tell us much about the institutional structure within which labor supply decisions are made, but little about the underlying utility parameters. Conversely Chetty (2006) argues that one can even uncover risk

\footnotetext{
39 Attanasio and Weber (2010) provide an excellent review of the life cycle literature, Hurst (2008) of the consumption retirement paradox.
} 
parameters more reliably from labor supply estimates than from study of financial market activities.

That said, consumption behavior in an analogous circumstance may provide considerable insight into the key question-would an additional lump of leisure increase or decrease the marginal utility of consumption and by how much? A number of scholars have appealed to the analogy of retirement consumption, including Chetty (2006). In an economy with abundant, inexpensive savings mechanisms, the extent to which individuals choose to smooth consumption across low leisure (working years) and high (retirement) should provide evidence on the ideal replacement rate, and indirectly on $u_{c \ell} \cdot{ }^{40}$ If workers plan their retirement, any observed decline in consumption presumably reflects optimal adjustments to increased leisure.

The early literature reported large drops in consumption at retirement, Table $1 .{ }^{41}$ In a highly structured life cycle model Mariger (1987) reported a drop of almost 50 percent. Banks, Blundell, and Tanner (1998) reported a drop in consumption of 42 percent (change in log consumption of -0.352) in a UK sample. If an optimal adjustment, this would suggest virtually all country replacement rates in Figure 2 may be first best. These early study results were labeled the "retirement consumption paradox" under the assumption that utility functions were additively separable, so that the simple life cycle consumption model must be rejected. More recent studies find much smaller consumption declines at retirement, especially when focused on workers without major life cycle disruptions. Evidence on this question is summarized in Table 1.

$<$ table 1>

\footnotetext{
40 This approach is muddled by the widely held belief that individuals are not competent to provide for their own retirements and will systematically undersave for their old age.

${ }^{41}$ See the extensive review by Attanasio and Weber (2010, Section 3.4).
} 
These early studies were not without empirical difficulties. Early consumption studies were often limited to food consumption (expenditures), while recent studies have raised concerns about using food consumption as a measure of overall consumption loss, Aguiar and Hurst (2005) and Hurst (2008). Hurst for example attributes the exaggerated decline in food consumption to an aspect of home production technology; food preparation is especially sensitive to available "leisure" time. Broader measures of expenditures reveal significant, but smaller drops in consumption at retirement, but these declines may reflect unexpected negative earnings shocks, plausibly health related, rather than the execution of a plan. For example Banks, Blundell, and Tanner (1998, p.769) argue that "The only way to reconcile the life cycle hypothesis (and additively separable utility) is with the systematic arrival of unexpected adverse information." Blau (2008), however, undertook an intensive calibration study of various earnings shocks and concluded:

...unexpected retirement alone cannot account for much of the drop in consumption at retirement observed in the data for the subset of households that do experience a drop. The calibrated model predicts a mean decline of 1-2 percentage points, while the data show a mean decline of about 12 percent. Other proposed explanations for the decline in consumption at retirement...[include] non-separable preferences, substitution of time for goods in home production, and bounded rationality...Blau (2008, p.67)

Bernheim, Skinner, and Weinberg (2001), Hurd and Rohwedder (2003), and Laitner and Silverman (2005) report estimates of consumption declines at retirement in the range of $15-20$ percent, Haider and Stephens (2007) and Battistin, Brugiavini, Rettore and Webber (2009) [on Italian data] report estimates of approximately 10 percent, At the lower bound of estimates, Hurd and Rohwedder (2007) report estimates in the range of 1-6 percent, and Aguia, Attanasio, and Meghir (2011) find essentially no effect for nondurables, but 5 percent for food.

Although the empirical results cover a wide range of possibilities, it would seem that retirees are not systematically setting aside greater consumption rights to complement their greater leisure, which in a utility framework implies that $u_{c \ell} \leq 0 .{ }^{42}$ In his critical review of the

\footnotetext{
${ }^{42}$ For an alternative interpretation of the evidence, Chetty (2006).
} 
literature, Hurst (2008) concluded that the decline in consumption at retirement among those who appear to retire voluntarily is perhaps 8 percent. This is perhaps an upper bound on firstbest consumption. If precautionary savings are warranted, consumption at retirement among those fortunate enough to avoid the early onset of a serious disability or job displacement from a long tenured job will exceed ideal levels.

\section{Conclusion}

Moral hazard issues are a central focus of the optimal unemployment insurance literature, providing a plausible explanation for unemployment insurance replacement rates substantially below 100 percent (Figure 1). As Blanchard and Tirole illustrated, however, firstbest UI may dictate UI replacement rates well below 100 percent. Indeed the utility model they use does not generate search moral hazard problems-in a standard model, optimal $\mathrm{UI}$ is moral-hazard-free. Layoff moral hazards (firing cost distortions) are also absent in the first-best contract, even if the firm fully funds first-best benefits for its workers.

Surprisingly, the B\&T model was widely used in early contracting models in the presence of unemployment, for example Azariadis (1975) and Baily (1974), although, for obvious reasons, not when moral hazard was being investigated. Subsequent studies that examined moral hazard issues employed a variety of utility models, including the additively separable model, with its heuristically attractive property of 100 percent replacement rates. CRRA and CARA functions with an embedded Cobb-Douglas composite argument are also common, especially in macro labor applications.

A standard neoclassical state utility function is developed to investigate the general conditions under which a moral-hazard-free first-best contract might arise. In this framework, a search moral-hazard-free outcome requires that the worker have an unusual relationship with leisure. A necessary condition is that the cross-derivative of the within state utility functions $\left(u_{c \ell}\right)$ be negative. This condition rules out the standard Cobb-Douglas (CD) form with positive 
exponents, for example, which implies a positive cross-partial derivative. It also rules out the additively separable model, in which $u_{c \ell}=0$. CRRA and CARA functions with an embedded Cobb-Douglas composite argument do offer the prospect of $u_{c \ell}$ less than zero (as long as the risk aversion parameter, often denoted gamma, exceeds one).

A negative cross-derivative is however not sufficient to generate SMHF contracts; resource reallocations from unemployment to employment must be sufficient to offset the direct gain in leisure that accrues to the unemployed. The Rosen Proposition asserts that leisure must be an inferior (or neutral) good in the state utility functions for SMHF contracts. None of the explicit models used in later optimal unemployment studies satisfy these conditions. In the CRRA and CARA models, for example, income effects are entirely determined by the CD composite element and are therefore normal.

LMHF contracts are more easily obtained. The LMHF condition is a financial one-the employer-insurer must not be tempted to misreport negative demand news in order to avoid separation benefit costs. A contract can be layoff moral-hazard-free either because expected separation costs are small or because these costs are sufficiently large that workers and employers negotiate (efficient) guaranteed employment contracts so that there are no layoffs (labor hoarding is efficient).

Empirical evidence strongly rejects the hypothesis that leisure is an inferior good, but still leaves open the possibility that optimal contracts may reduce, if not eliminate, moral hazard effects-- $u_{c \ell}$ is negative, but not "negative enough." The retirement consumption literature provides important insight into the shape of the utility element in a situation of allocating consumption and leisure (across time instead of states). Among workers who receive no negative surprises across their work lives, how does consumption vary between the last working years and the first retirement years? Early studies seemed to suggest that low replacement rates observed in various countries, essentially 50-80 percent, could be almost entirely 
explained by first-best design calculations. The more recent literature has narrowed that margin however, indicating that a 10-20 percent drop might be first best, with the rest potentially moral hazard induced. The wide range of estimates indicates that much remains to be done in identifying first-best unemployment insurance benefits. Ongoing research should improve our understanding of the first-best $\mathrm{UI}$ benefit, but the evidence to date suggests that the first-best replacement rate is below 100 percent, perhaps well below, easing moral hazard concerns, if not eliminating them. 


\section{References}

Acemoglu, Daron, and Robert Shimer. 1999. "Efficient Unemployment Insurance." Journal of Political Economy. v107.5 (October): 893-928.

Acemoglu, Daron, and Robert Shimer, 2000. "Productivity Gains from Unemployment Insurance," European Economic Review 44.7 (June): 1195-1224.

Aguiar, Mark, and Erik Hurst. 2005. Consumption versus Expenditure. Journal of Political Economy. v.113.5 919-948.

Aguiar, Mark A., Erik Hurst, and Loukas Karabarbounis. 2013. "Time Use during the Great Recession." American Economic Review, v103.5 (August): 1664-9

Aguila, Emma, Orazio Attanasio, and Costas Meghir. 2011. "Changes in Consumption at Retirement: Evidence from Panel Data." The Review of Economics and Statistics 93.3 (August): 1094-1099.

Attanasio, Orazio P. and Guglielmo Weber. 1993. "Consumption Growth, the Interest Rate and Aggregation." Review of Economic Studies. v60.3 (July): 631-49.

Attanasio, Orazio P. and Guglielmo Weber. 1995. "Is Consumption Growth Consistent with Intertemporal Optimization? Evidence from the Consumer Expenditure Survey," Journal of Political Economy. v103.6 (December): 1121-57.

Attanasio, Orazio P. and Guglielmo Weber. 2010. "Consumption and Saving: Models of Intertemporal Allocation and Their Implications for Public Policy." Journal of Economic Literature. v48.3 (September): 693-751.

Azariadis, Costas. 1975. "Implicit Contracts and Underemployment Equilibria," Journal of Political Economy, 83 (December): 1183-1202.

Baily, Martin Neil. 1974. "Wages and Employment under Uncertain Demand" Review of Economic Studies 41.1 (January): 37-50.

Baily, Martin Neil. 1977. "Unemployment Insurance.as Insurance for Workers" Industrial and Labor Relations Review 30 (July): 495-504.

Baily, Martin Neil. 1978. "Some Aspects of Optimal Unemployment Insurance" Journal of Public Economics v10.3 (December): 379-402.

Banks, James; Richard Blundell, and Sarah Tanner. 1998. "Is There a Retirement-Savings Puzzle?" American Economic Review, 88.4 (September): 769-88.

Battistin, Erich, Agar Brugiavini, Enrico Rettore, and Guglielmo Weber. 2009. "The Retirement Consumption Puzzle: Evidence from a Regression Discontinuity Approach.” American Economic Review 99:5, 2209-2226.

Bernheim, B. Douglas, Jonathan Skinner, and Steven Weinberg. 2001. "What Accounts for the Variation in Retirement Wealth among U.S. Households?" American Economic Review, 91 (September): 832-857.

Blanchard, Olivier J., and Jean Tirole. 2008. "The Joint Design of Unemployment Insurance and Employment Protection: A First Pass," Journal of the European Economic Association v.6(1) March: 45-77.

Blau, David M. 2008. "Retirement and Consumption in a Life Cycle Model." Journal of Labor Economics, 26.1 (January): 35-71. 
Blundell, Richard; Luigi Pistaferri, and Ian Preston. 2008. "Consumption Inequality and Partial Insurance." American Economic Review, v.98.5 (December): 1887-1921.

Chetty, Raj. 2006. "A New Method of Estimating Risk Aversion." American Economic Review, v.96.5 (December): 1821-34.

Chetty, Raj. 2008. "Moral Hazard versus Liquidity and Optimal Unemployment Insurance." Journal of Political Economy, v116.2 (April): 173-234.

Emerson, Michael. 1988. "Regulation or Deregulation of the Labour Market; Policy Regimes for the Recruitment and Dismissal of Employees in the Industrialized Countries," European Economic Review 32 (1988): 775-817.

Flemming, J. S. 1978. "Aspects of Optimal Unemployment Insurance: Search, Leisure, Savings and Capital Market Imperfections." Journal of Public Economics. v10.3 (December): 40325.

Fredriksson, Peter, and Bertil Holmlund. 2006. "Improving Incentives in Unemployment Insurance: A Review of Recent Research," Journal of Economic Surveys, vol.20.3: 357386.

Haber, William, and Merrill G. Murray. 1968. Unemployment Insurance in the American Economy: An Historical Review and Analysis. Richard D. Irwin: Homewood, IL.

Haider, Steven J., and Melvin Stephens Jr. 2007. "Is there a Retirement-Consumption Puzzle? Evidence using Subjective Retirement Expectations, Review of Economics and Statistics, v89.2 (May): 247-264.

Hansen, Gary D. and Ayse Imrohoroglu. 1992. "The Role of Unemployment Insurance in an Economy with Liquidity Constraints and Moral Hazard," Journal of Political Economy, v100.1 (February): 118-42.

Heathcote, Jonathan, Kjetil, Storesletten, and Giovanni L. Violante. 2014. "Consumption and Labor Supply with Partial Insurance: An Analytical Framework." American Economic Review. v104.7 (July): 2075-2126.

Heckman, James J. 1974 "Life Cycle Consumption and Labor Supply: An Explanation of the Relationship Between Income and Consumption Over the Life Cycle," American Economic Review (March) 64.1, 188-94

Heckman, James J., and Carmen Pagés. 2004. "Introduction," in Heckman and Pagés, eds., Law and Employment: Lessons from Latin America and the Caribbean, Chicago, The University of Chicago: 1-107.

Holmlund, Bertil. 1998. "Unemployment Insurance in Theory and Practice," Scandinavian Journal of Economics, 100(1): 113-141.

Holzmann, Robert, Yann Pouget, Michael Weber, and Milan Vodopivec. 2012. "Severance Pay Programs around the World: History, Rationale, Status, and Reforms" In Robert Holzmann and Milan Vodopivec, eds. Reforming Severance Pay: An International Perspective, Washington, DC: World Bank: 17-120.

Hopenhayn, Hugo A. and Juan Pablo Nicolini. 1997. "Optimal Unemployment Insurance," Journal of Political Economy, 105.2 (April): 412-438. 
Hurd, Michael D., and Susann Rohwedder. 2003. "The Retirement-Consumption Puzzle: Anticipated and Actual Declines in Spending at Retirement" National Bureau of Economic Research, Inc., NBER Working Papers: 9586.

Hurd, Michael D., and Susann Rohwedder. 2008. "The Retirement Consumption Puzzle: Actual Spending Change in Panel Data." National Bureau of Economic Research, Inc., NBER Working Papers: 13929.

Hurst, Erik. 2008. "The Retirement of a Consumption Puzzle" National Bureau of Economic Research Working Paper 13789 (February).

Karni, Edi, "Optimal Unemployment Insurance: A Survey" 1999. Southern Economic Journal, 66 (October): 442-65.

Keene, Michael, and Richard Rogerson, 2012. "Micro and Macro Labor Supply Elasticities: A Reassessment of Conventional Wisdom," Journal of Economic Literature 50.2, 464-476.

Krueger, Alan B., and Andreas Mueller. 2008. "The Lot of the Unemployed: A Time Use Perspective." IZA DP 3490. (May)

Laitner, John, and Dan Silverman. 2005. Estimating life-cycle parameters from consumption behavior at retirement, Working Paper no. 11163, National Bureau of Economic Research, Cambridge, MA.

Lazear, Edward P. 1990. "Job Security Provisions and Employment," Quarterly Journal of Economics 105 (August), 699-726.

Lindbeck, Assar. 1995. "Hazardous Welfare-State Dynamics," American Economic Review, v85.3 (May): 9-15.

MaCurdy, Thomas E. 1981. "An Empirical Model of Labor Supply in a Life-Cycle Setting." Journal of Political Economy, v.89.6 (December): 1059-85.

Malcomson, J. 1999. "Individual Employment Contracts," in Orley Ashenfelter and David Card, eds. Handbook of Labor Economics, Vol. IIIB, Chapter 35, North Holland Press pp.2291-2372.

Mankiw, M. Gregory. Julio J. Rotemberg, and Lawrence H. Summers. 1985. "Intertemporal Substitution in Macroeconomics." Quarterly Journal of Economics. 225-251.

Mariger, Randall P. 1987. "A Life-cycle Consumption Model with Liquidity Contraints: Theory and Empirical Results." Econometrica. v.55.3. (May): 533-57.

Mortensen, Dale T., 1977. "Unemployment Insurance and the Job Search Decision" Industrial and Labor Relations Review. 30 (July): 505-517.

OECD. 2006. OECD Employment Outlook, Table 3.2. Net replacement rates and unemployment insurance benefit duration. p.60.

O'Leary, Christopher J., and Murray A. Rubin. 1997. "The Adequacy of the Weekly Benefit Amount," in Christopher J. O'Leary and Stephen A. Wandner, eds. Unemployment Insurance in the United States: Analysis of Policy Issues. Kalamazoo, MI; W.E. Upjohn Institute for Employment Research: 163-201.

Parsons, Donald O. 1986. "The Employment Relationship: Job Attachment, Work Effort, and the Nature of Contracts" in Orley Ashenfelter and Richard Layard, eds. Handbook of Labor Economics, Vol. II, North Holland Press: 789-848. 
Parsons, Donald O. 1991. "'The Job Search Behavior of Employed Youth", Review of Economics and Statistics (November) 597-604.

Parsons, Donald O. 2012a. "Mandated Severance Pay and Firing Cost Distortions: A Critical Review of the Evidence," Chapter 3 in Robert Holzmann and Milan Vodopivec, eds., Reforming Severance Pay: An International Perspective, Washington, DC: World Bank, 121-157.

Parsons, Donald O. 2012b. "The Firing Cost Implications of Alternative Severance Pay Designs" Chapter 4 In Robert Holzmann and Milan Vodopivec, eds., Reforming Severance Pay: An International Perspective, Washington, DC: World Bank, 2012, 159-176.

Pissarides, Christopher A. 2010 "Why Do Firms Offer 'Employment Protection'?” Economica 77, 613-636

Rogerson, Richard; and Martin Schindler. 2002. "The Welfare Costs of Worker Displacement," Journal of Monetary Economics v49.6 (September): 1213-34.

Rosen, Sherwin. 1985. "Implicit Contracts: A Survey." Journal of Economic Perspectives. v23 (September): 1144-1175.

Salanié, Bernard. 2005. The Economics of Contracts: A Primer, Second Edition, MIT Press.

Shavell, Steven and Weiss, Laurence. "The Optimal Payment of Unemployment Insurance Benefits over Time.” Journal of Political Economy 87 (December 1979): 1347-1362.

Shimer, Robert, and Ivan Werning. 2008. "Liquidity and Insurance for the Unemployed." American Economic Review v.98.5 (December): 1922-1942.

U.S Social Security Administration, Social Security throughout the World: SSA Americas 2009, Table 1 pp.17-18; SSA Africa 2009, Table 1, pp. 17-18; SSA Asia, 2010 Table 1 pp.1718; SSA Europe 2010, Table 1, pp. 17-18.

https://www.ssa.gov/policy/docs/progdesc/ssptw/. 
Table 1

Consumption Decline at Retirement

\begin{tabular}{|c|c|c|c|c|}
\hline Study & $\begin{array}{l}\text { Country/ } \\
\text { Data }\end{array}$ & $\begin{array}{c}\text { Consumption } \\
\text { Measure }\end{array}$ & $\begin{array}{c}\text { Consumption } \\
\text { Decline }\end{array}$ & Remarks \\
\hline Mariger (1987) & $\begin{array}{l}\text { U.S.I } \\
\text { SCFCC }\end{array}$ & $\begin{array}{l}\text { Gross cash } \\
\text { receipts plus } \\
\text { implicit service } \\
\text { flows from } \\
\text { durables. }\end{array}$ & $47 \%$ & $\begin{array}{l}\text { Structured Life } \\
\text { Cycle Model }\end{array}$ \\
\hline $\begin{array}{l}\text { Banks, Blundell, } \\
\text { and Tanner } \\
\text { (1998) }\end{array}$ & U.K./FES & $\begin{array}{l}\text { Nondurables } \\
\text { (Excludes Large } \\
\text { Household } \\
\text { Durables) }\end{array}$ & $42 \%$ & $\begin{array}{l}\text { Change in log } \\
\text { consumption } \\
-0.352\end{array}$ \\
\hline $\begin{array}{l}\text { Bernheim, } \\
\text { Skinner, and } \\
\text { Weinberg (2001) }\end{array}$ & $\begin{array}{l}\text { U.S./PSID, } \\
\text { CEX }\end{array}$ & $\begin{array}{l}\text { Total } \\
\text { Consumption }\end{array}$ & $15 \%$ & $\begin{array}{l}\text { Change in In } \\
\text { consumption } \\
-.014\end{array}$ \\
\hline $\begin{array}{l}\text { Hurd and } \\
\text { Rohwedder } \\
\text { (2003) }\end{array}$ & $\begin{array}{l}\text { U.S./HRS, } \\
\text { CAMS }\end{array}$ & Total Spending & 15 to $20 \%$ & $\begin{array}{l}\text { Actual and } \\
\text { Anticipated }\end{array}$ \\
\hline $\begin{array}{l}\text { Laitner and } \\
\text { Silverman (2005) }\end{array}$ & U.S./CEX & Total & $16 \%$ & \\
\hline $\begin{array}{l}\text { Hurd and } \\
\text { Rohwedder } \\
\text { (2007) }\end{array}$ & $\begin{array}{l}\text { U.S./HRS, } \\
\text { CAMS }\end{array}$ & $\begin{array}{l}\text { Total } \\
\text { Nondurable }\end{array}$ & 1 to $6 \%$ & \\
\hline $\begin{array}{l}\text { Haider and } \\
\text { Stephens (2007) }\end{array}$ & $\begin{array}{l}\text { U.S./RHS, } \\
\text { HRS, PSID }\end{array}$ & Food & $\begin{array}{l}9 \% \text { RHS } \\
9 \% \text { PSID } \\
0 \% \text { HRS }\end{array}$ & \\
\hline Blau (2008) & U.S./CAMS & & $10 \%$ & $\begin{array}{l}12 \% \\
\text { unadjusted for } \\
\text { involuntary exit }\end{array}$ \\
\hline $\begin{array}{l}\text { Battistin, } \\
\text { Brugiavini, } \\
\text { Rettore, and } \\
\text { Weber (2009) }\end{array}$ & Italy/SHIW & Nondurables & $9.8 \%$ & $\begin{array}{l}\text { Perhaps half } \\
\text { explained by } \\
\text { reduction in } \\
\text { offspring } \\
\text { coresidence }\end{array}$ \\
\hline $\begin{array}{l}\text { Aguila, Attanasio } \\
\text { and Meghir (2011) }\end{array}$ & U.S./CEX & $\begin{array}{l}\text { Nondurables, } \\
\text { Food }\end{array}$ & $\begin{array}{c}0 \% \text { (Nondur) } \\
5 \% \text { (Food) }\end{array}$ & \\
\hline
\end{tabular}

CAMS Consumption and Activities Mail Survey (HRS respondents)

CEX Consumer Expenditure Survey

FES Family Expenditure Survey

HRS Health and Retirement Study

PSID Panel Study of Income Dynamics

RHS Retirement History Survey

SCFCC Federal Reserve Survey of Changes in Financial Characteristics of Consumers (1964)

SHIW Bank of Italy Survey of Household Income and Wealth 
Figure 1

Unemployment Insurance Replacement Rates

Nineteen OECD Countries, 2004 OECD (2006) and 2009-10 SSA (2009-2010)

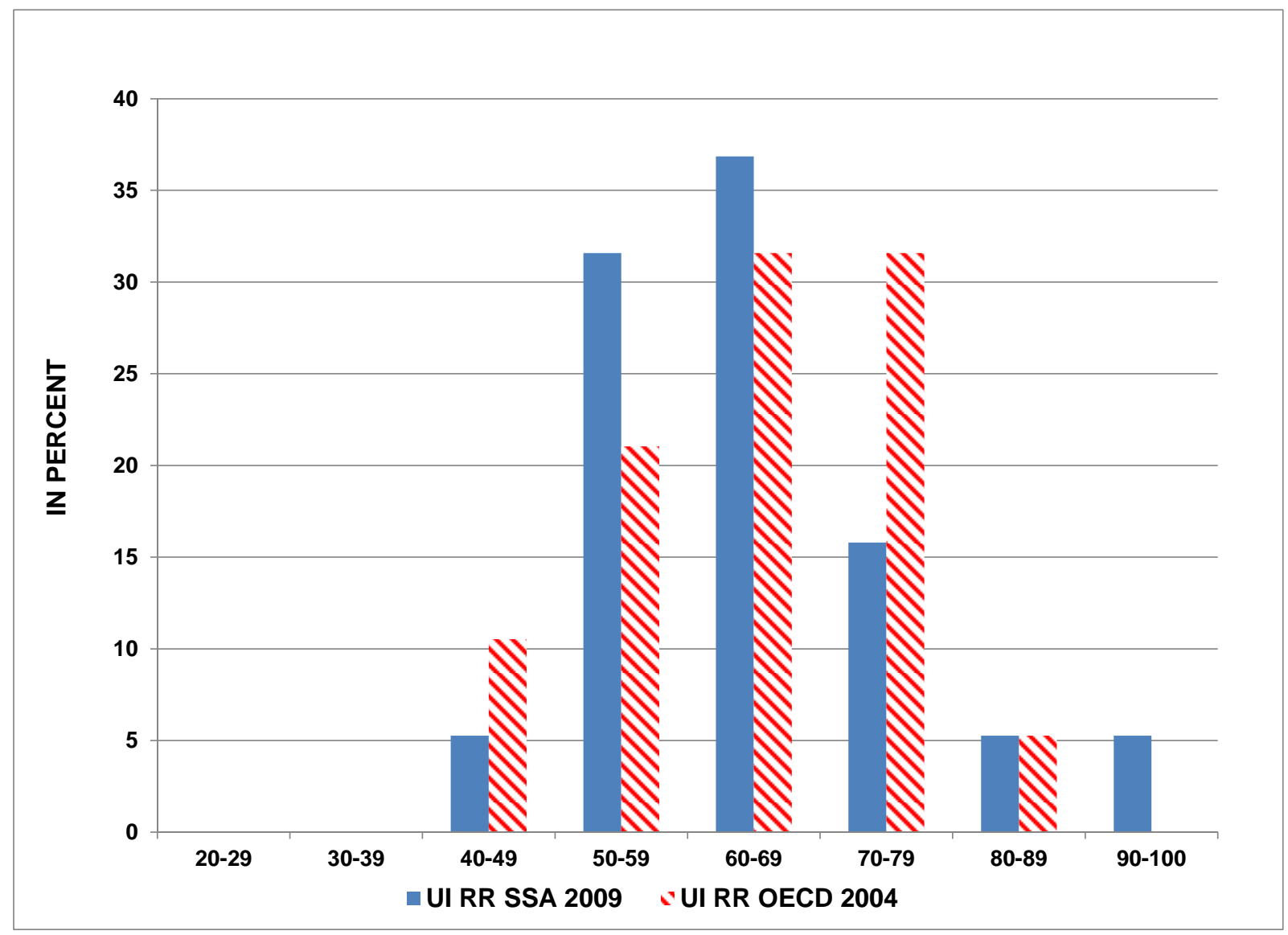


Figure 2

Daily Time Use (in Minutes) of Employed and Unemployed in the United States Krueger Mueller (2008, Table 3)

Panel A: Weekday

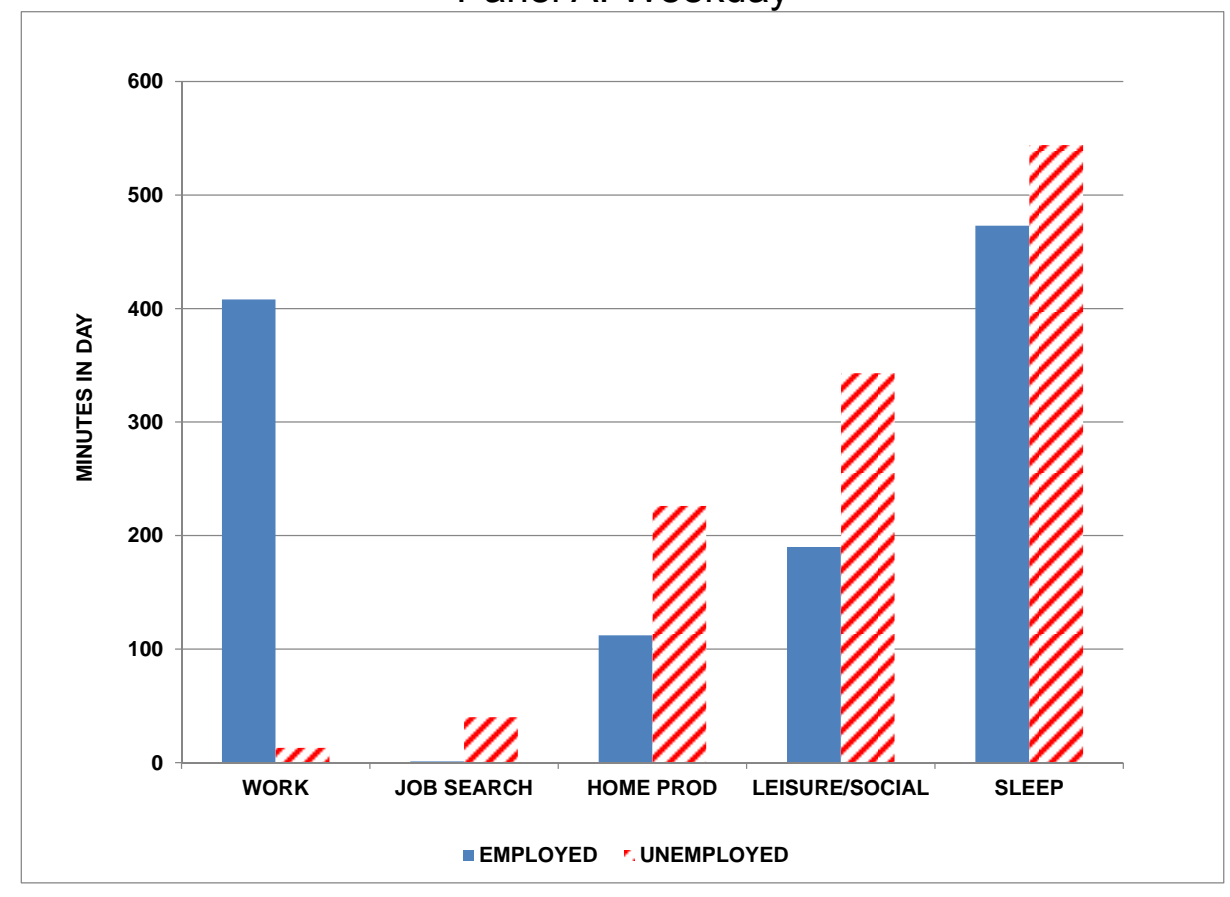

Panel B: Weekend Day

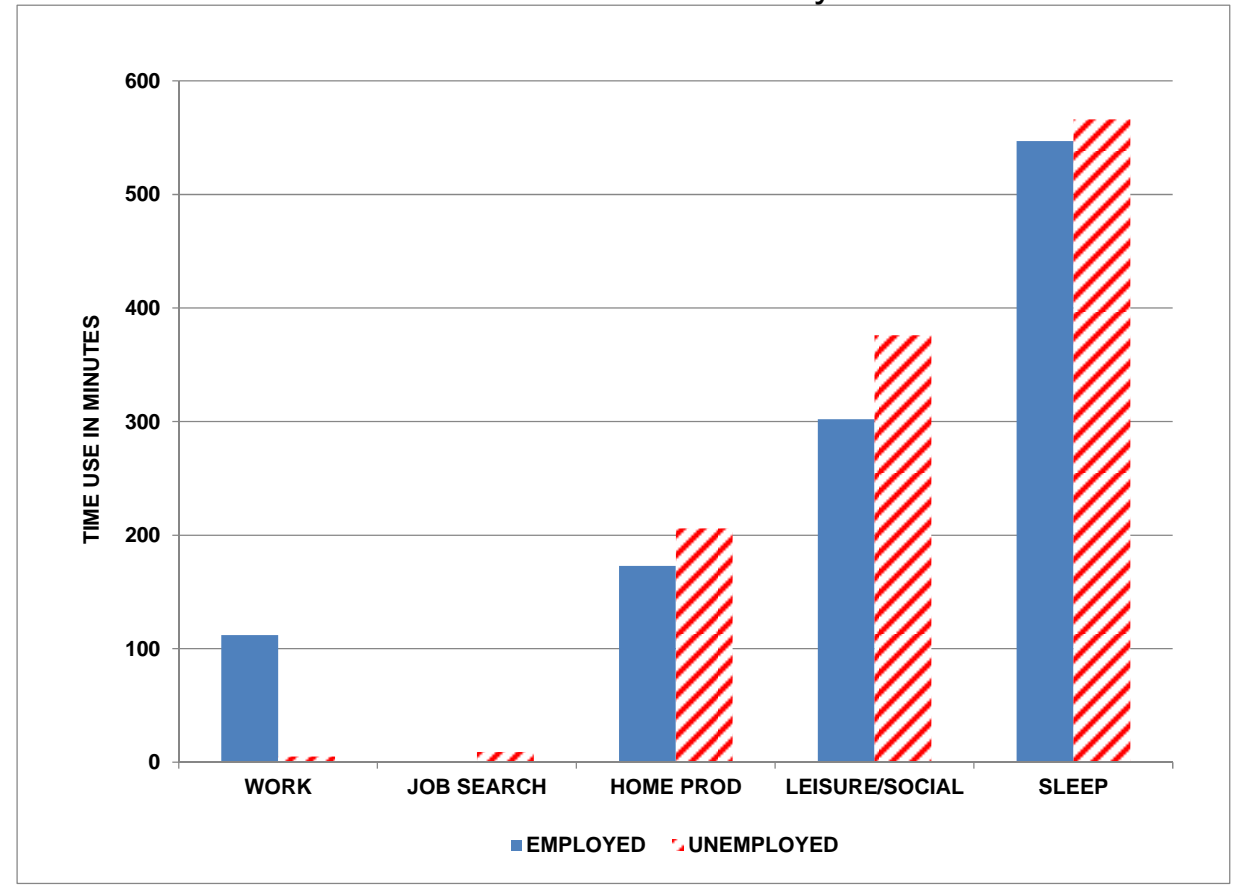




\section{Appendix 1}

The Blanchard and Tirole Model (Modified)

Consider the B\&T employment contract, with no option to work in the unemployed state (2) and fixed leisure in both states, though greater in unemployment: $\hat{\ell}_{2}>\hat{\ell}_{1}$. Forming the Lagrangian in consumption:

$$
\begin{aligned}
\mathcal{L}=\rho u\left(C_{1}^{*}\right. & \left.+\mu \hat{\ell}_{1}\right)+(1-\rho) u\left(C_{2}^{*}+\mu \hat{\ell}_{2}\right) \\
& -\lambda\left(\rho C_{1}^{*}+(1-\rho) C_{2}^{*}-\rho v\left(1-\hat{\ell}_{1}\right)-I_{0}\right)
\end{aligned}
$$

The first order conditions simplify to:

$$
\begin{aligned}
& u\left(C_{1}^{*}+\mu \hat{\ell}_{1}\right)-\lambda=0, \\
& u\left(C_{2}^{*}+\mu \hat{\ell}_{2}\right)-\lambda=0, \\
& \rho C_{1}^{*}+(1-\rho) C_{2}^{*}-\rho v\left(1-\hat{\ell}_{1}\right)-I_{0}=0 .
\end{aligned}
$$

Equations (A2a) and (A2b) imply that

$$
\begin{aligned}
& C_{1}^{*}+\mu \hat{\ell}_{1}=C_{2}^{*}+\mu \hat{\ell}_{2}, \text { or } \\
& C_{1}^{*}=C_{2}^{*}+\mu\left(\hat{\ell}_{2}-\hat{\ell}_{1}\right),
\end{aligned}
$$

Which, when combined with $A 2 c$, yields

$$
\begin{aligned}
& C_{1}^{*}=\rho v\left(1-\hat{\ell}_{1}\right)+I_{0}+(1-\rho) \mu\left(\hat{\ell}_{2}-\hat{\ell}_{1}\right) \\
& C_{2}^{*}=\rho v\left(1-\hat{\ell}_{1}\right)+I_{0}-\rho \mu\left(\hat{\ell}_{2}-\hat{\ell}_{1}\right) .
\end{aligned}
$$




\section{Appendix 2}

The Guaranteed Employment Model with Neoclassical Utility

Forming the Lagrangian in consumption:

$$
\begin{aligned}
& \mathcal{L}=\rho u\left(C_{1}, \ell_{1}\right)+(1-\rho) u\left(C_{2}, \ell_{2}\right) \\
& -\lambda\left(\rho C_{1}+(1-\rho) C_{2}-\rho v\left(1-\ell_{1}\right)-(1-\rho) \theta v\left(1-\ell_{2}\right)-I_{0}\right)
\end{aligned}
$$

The first order conditions simplify to:

$$
\begin{aligned}
& u_{C}\left(C_{1}, \ell_{1}\right)-\lambda=0, \\
& u_{\ell}\left(C_{1}, \ell_{1}\right)-\lambda v=0, \\
& u_{C}\left(C_{2}, \ell_{2}\right)-\lambda=0, \\
& u_{\ell}\left(C_{2}, \ell_{2}\right)-\lambda \theta v=0, \quad \text { and } \\
& \rho C_{1}+(1-\rho) C_{2}-\rho v\left(1-\ell_{1}\right)-(1-\rho) \theta v\left(1-\ell_{2}\right)-I_{0}=0 .
\end{aligned}
$$

Clearly the marginal utility of consumption must be equal across the two states, but consumption need not, because the ratio of leisure marginal utilities in the GE contract should equal the ratio of productivity in the two states. Work hours are flexible, and one could expect the worker to work more in the high demand state, less in the low demand state.

Alternatively one might expect that an increment in $\theta$ will decrease leisure in the low demand state, and increase it in the high demand state. The impact on consumption will depend on the cross-partial of the utility function $u_{C \ell}$. If $u_{C \ell}<0$, the worker will demand higher consumption in the good state and lower consumption in the bad, but the converse will hold if $u_{C \ell}<0$.

Assume that the sufficient conditions hold.

To explore the comparative statics of this system, we form the second order differential of this system which in matrix form is: 


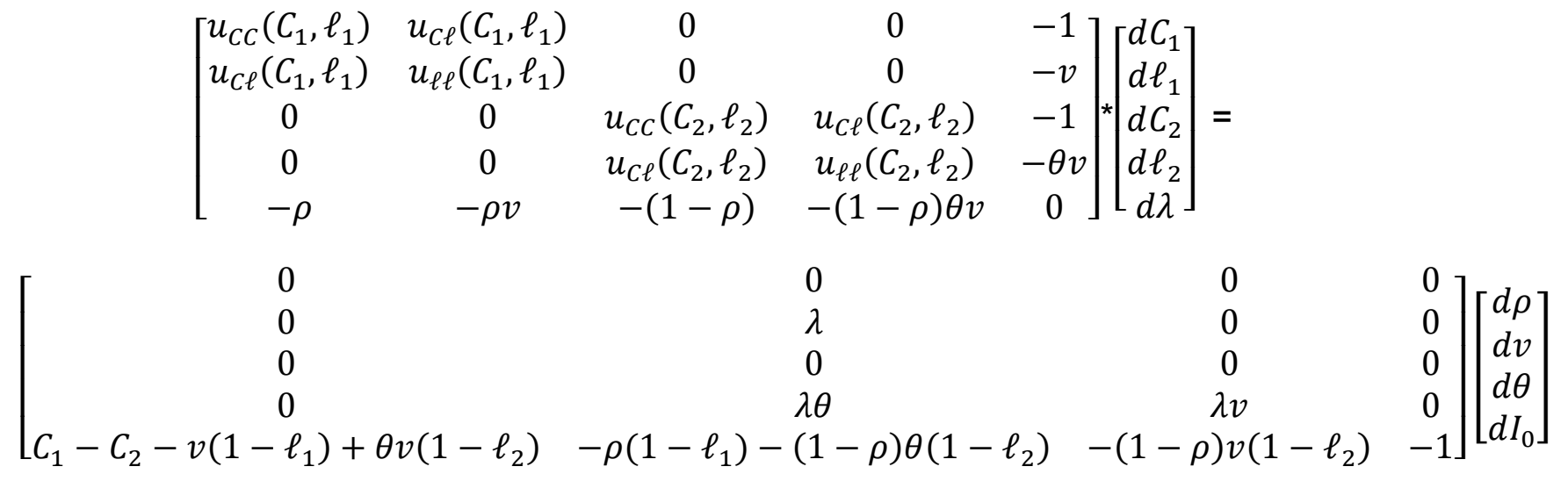

Sufficient conditions for this system to represent an interior maximum include $\Delta>0$ :

$$
\begin{gathered}
\Delta=\left|\begin{array}{ccccc}
u_{C C}\left(C_{1}, \ell_{1}\right) & u_{C \ell}\left(C_{1}, \ell_{1}\right) & 0 & 0 & -1 \\
u_{C \ell}\left(C_{1}, \ell_{1}\right) & u_{\ell \ell}\left(C_{1}, \ell_{1}\right) & 0 & 0 & -v \\
0 & 0 & u_{C C}\left(C_{2}, \ell_{2}\right) & u_{C \ell}\left(C_{2}, \ell_{2}\right) & -1 \\
0 & 0 & u_{C \ell}\left(C_{2}, \ell_{2}\right) & u_{\ell \ell}\left(C_{2}, \ell_{2}\right) & -\theta v \\
-\rho & -\rho v & -(1-\rho) & -(1-\rho) \theta v & 0
\end{array}\right| \\
=\rho\left[2 \mathrm{vu}_{\mathrm{C} \ell}\left(\mathrm{C}_{1}, \ell_{1}\right)-\mathrm{v}^{2} \mathrm{u}_{\mathrm{CC}}\left(\mathrm{C}_{1}, \ell_{1}\right)-\mathrm{u}_{\ell \ell}\left(\mathrm{C}_{1}, \ell_{1}\right)\right] \\
*\left[\mathrm{u}_{\mathrm{CC}}\left(\mathrm{C}_{2}, \ell_{2}\right) \mathrm{u}_{\ell \ell}\left(\mathrm{C}_{2}, \ell_{2}\right)-\left[\mathrm{u}_{\mathrm{C} \ell}\left(\mathrm{C}_{2}, \ell_{2}\right)\right]^{2}\right] \\
+(1-\rho)\left[2(\theta \mathrm{v}) \mathrm{u}_{\mathrm{C} \ell}\left(\mathrm{C}_{2}, \ell_{2}\right)-(\theta \mathrm{v})^{2} \mathrm{u}_{\mathrm{CC}}\left(\mathrm{C}_{2}, \ell_{2}\right)-\mathrm{u}_{\ell \ell}\left(\mathrm{C}_{2}, \ell_{2}\right)\right] \\
*\left[\mathrm{u}_{\mathrm{CC}}\left(\mathrm{C}_{1}, \ell_{1}\right) \mathrm{u}_{\ell \ell}\left(\mathrm{C}_{1}, \ell_{1}\right)-\left[\mathrm{u}_{\mathrm{C} \ell}\left(\mathrm{C}_{1}, \ell_{1}\right)\right]^{2}\right]
\end{gathered}
$$

Expect impact of theta second period productivity $\theta$ to be largely substitution effect $\left(\frac{d \ell_{2}}{d \theta}<0\right)$.

$$
\frac{d \ell_{2}}{d \theta}=\frac{1}{\Delta}\left[\begin{array}{ccccc}
u_{C C}\left(C_{1}, \ell_{1}\right) & u_{C \ell}\left(C_{1}, \ell_{1}\right) & 0 & 0 & -1 \\
u_{C \ell}\left(C_{1}, \ell_{1}\right) & u_{\ell \ell}\left(C_{1}, \ell_{1}\right) & 0 & 0 & -v \\
0 & 0 & u_{C C}\left(C_{2}, \ell_{2}\right) & 0 & -1 \\
0 & 0 & u_{C \ell}\left(C_{2}, \ell_{2}\right) & \theta v & -\theta v \\
-\rho & -\rho v & -(1-\rho) & C & 0
\end{array}\right]
$$




$$
\begin{gathered}
=(1-\rho) v\left(1-\ell_{2}\right) \frac{d \ell_{2}}{d I_{0}} \\
+\frac{1}{\Delta} \theta v\left[\rho u_{C C}\left(C_{2}, \ell_{2}\right)\left[2 v u_{C \ell}\left(C_{1}, \ell_{1}\right)-v^{2} u_{C C}\left(C_{1}, \ell_{1}\right)-u_{\ell \ell}\left(C_{1}, \ell_{1}\right)\right]\right. \\
\left.-(1-\rho)\left[\left\{u_{C \ell}\left(C_{1}, \ell_{1}\right)\right\}^{2}-u_{C C}\left(C_{1}, \ell_{1}\right) u_{\ell \ell}\left(C_{1}, \ell_{1}\right)\right]\right]
\end{gathered}
$$

Now if $\boldsymbol{\rho} \rightarrow \mathbf{1}$ (limiting the residual income effect embedded in $d \theta$ ).

$$
\begin{aligned}
\frac{d \ell_{2}}{d \theta} \rightarrow & \frac{1}{\Delta} \theta v u_{C C}\left(C_{2}, \ell_{2}\right)\left[2 v u_{C \ell}\left(C_{1}, \ell_{1}\right)-v^{2} u_{C C}\left(C_{1}, \ell_{1}\right)-u_{\ell \ell}\left(C_{1}, \ell_{1}\right)\right] \\
& =\frac{\theta v u_{C C}\left(C_{2}, \ell_{2}\right)}{\mathrm{u}_{C C}\left(\mathrm{C}_{2}, \ell_{2}\right) \mathrm{u}_{\ell \ell}\left(\mathrm{C}_{2}, \ell_{2}\right)-\left[\mathrm{u}_{C \ell}\left(\mathrm{C}_{2}, \ell_{2}\right)\right]^{2}}<0
\end{aligned}
$$




\section{Appendix 3}

The Layoff Model with Neoclassical Utility

Of special interest in the analysis of moral hazard issues is the impact of $\hat{\ell}_{2}$ on the worker's contract with the firm in the layoff contract. Forming the Lagrangian of the optimization problem (in consumption form):

$$
\begin{aligned}
\mathcal{L}=\rho u & \left(C_{1}, \ell_{1}\right)+(1-\rho) u\left(C_{2}, \hat{\ell}_{2}\right) \\
& -\lambda\left(\rho C_{1}+(1-\rho) C_{2}-\rho v\left(1-\ell_{1}\right)-I_{0}\right)
\end{aligned}
$$

The first order conditions simplify to:

$$
\begin{aligned}
& u_{C}\left(C_{1}, \ell_{1}\right)-\lambda=0 \\
& u_{\ell}\left(C_{1}, \ell_{1}\right)-\lambda v=0 \\
& u_{C}\left(C_{2}, \hat{\ell}_{2}\right)-\lambda=0 \\
& \rho C_{1}+(1-\rho) C_{2}-\rho v\left(1-\ell_{1}\right)-I_{0}=0
\end{aligned}
$$

Some features of the first-best contract are obvious, including the equality of marginal utilities of consumption across states, A2a and A2c. In general this will not lead to the equality of consumption across states because leisure varies. Leisure in the unemployed outcome is of course not a choice variable.

Sufficient conditions for this system to represent an interior maximum include $\Delta<0$, where:

$$
\begin{gathered}
\Delta=\left|\begin{array}{cccc}
u_{C C}\left(C_{1}, \ell_{1}\right) & u_{C \ell}\left(C_{1}, \ell_{1}\right) & 0 & -1 \\
u_{C \ell}\left(C_{1}, \ell_{1}\right) & u_{\ell \ell}\left(C_{1}, \ell_{1}\right) & 0 & -v \\
0 & 0 & u_{C C}\left(C_{2}, \hat{\ell}_{2}\right) & -1 \\
-\rho & -\rho v & -(1-\rho) & 0
\end{array}\right| \\
=\rho u_{C C}\left(C_{2}, \hat{\ell}_{2}\right)\left[2 v u_{C \ell}\left(C_{1}, \ell_{1}\right)-u_{\ell \ell}\left(C_{1}, \ell_{1}\right)-v^{2} u_{C C}\left(C_{1}, \ell_{1}\right)\right] \\
+(1-\rho)\left[\left(u_{C \ell}\left(C_{1}, \ell_{1}\right)\right)^{2}-u_{C C}\left(C_{1}, \ell_{1}\right) u_{\ell \ell}\left(C_{1}, \ell_{1}\right)\right] .
\end{gathered}
$$

Both terms are negative under the assumptions of the model, so $\Delta<0$. 
To explore the comparative statics of this system, form the second order differential of this system which in matrix form is:

$$
\begin{gathered}
{\left[\begin{array}{cccc}
u_{C C}\left(C_{1}, \ell_{1}\right) & u_{C \ell}\left(C_{1}, \ell_{1}\right) & 0 & -1 \\
u_{C \ell}\left(C_{1}, \ell_{1}\right) & u_{\ell \ell}\left(C_{1}, \ell_{1}\right) & 0 & -v \\
0 & 0 & u_{C C}\left(C_{2}, \hat{\ell}_{2}\right) & -1 \\
-\rho & -\rho v & -(1-\rho) & 0
\end{array}\right] *\left[\begin{array}{c}
d C_{1} \\
d \ell_{1} \\
d C_{2} \\
d \lambda
\end{array}\right]=} \\
\quad\left[\begin{array}{ccc}
0 & 0 & 0 \\
\lambda & 0 & 0 \\
0 & -u_{C \ell}\left(C_{2}, \hat{\ell}_{2}\right) & 0 \\
-\rho\left(1-\ell_{1}\right) & 0 & -1
\end{array}\right]\left[\begin{array}{l}
d v \\
d \hat{\ell}_{2} \\
d I_{0}
\end{array}\right] \\
\frac{d C_{2}}{d \hat{\ell}_{2}}=\frac{1}{\Delta} \rho u_{C \ell}\left(C_{2}, \hat{\ell}_{2}\right)\left[u_{\ell \ell}\left(C_{1}, \ell_{1}\right)+v^{2} u_{C C}\left(C_{1}, \ell_{1}\right)-2 v u_{C \ell}\left(C_{1}, \ell_{1}\right)\right] \\
\frac{d C_{1}}{d \hat{\ell}_{2}}= \\
=\frac{1}{\Delta}(1-\rho) u_{C \ell}\left(C_{2}, \hat{\ell}_{2}\right)\left[v u_{C \ell}\left(C_{1}, \ell_{1}\right)-u_{\ell \ell}\left(C_{1}, \ell_{1}\right)\right] \\
\frac{(1-\rho)}{\rho}\left[\frac{v u_{C \ell}\left(C_{1}, \ell_{1}\right)-u_{\ell \ell}\left(C_{1}, \ell_{1}\right)}{u_{\ell \ell}\left(C_{1}, \ell_{1}\right)+v^{2} u_{C C}\left(C_{1}, \ell_{1}\right)-2 v u_{C \ell}\left(C_{1}, \ell_{1}\right)}\right] \frac{d C_{2}}{d \hat{\ell}_{2}} \\
\frac{d C_{1}}{d \hat{\ell}_{2}}=
\end{gathered}
$$

The same notions apply to leisure choice in the employed state.

$$
\begin{gathered}
\frac{d \ell_{1}}{d \hat{\ell}_{2}}=\frac{1}{\Delta}(1-\rho) u_{C \ell}\left(C_{2}, \hat{\ell}_{2}\right)\left[u_{C \ell}\left(C_{1}, \ell_{1}\right)-v u_{C C}\left(C_{1}, \ell_{1}\right)\right] \\
=\frac{(1-\rho)}{\rho}\left[\frac{u_{C \ell}\left(C_{1}, \ell_{1}\right)-v u_{C C}\left(C_{1}, \ell_{1}\right)}{u_{\ell \ell}\left(C_{1}, \ell_{1}\right)+v^{2} u_{C C}\left(C_{1}, \ell_{1}\right)-2 v u_{C \ell}\left(C_{1}, \ell_{1}\right)}\right] \frac{d C_{2}}{d \hat{\ell}_{2}} \\
\frac{d \ell_{1}}{d I_{0}}=\frac{1}{\Delta} u_{C C}\left(C_{2}, \hat{\ell}_{2}\right)\left\{\left[u_{C \ell}\left(C_{1}, \ell_{1}\right)-v u_{C C}\left(C_{1}, \ell_{1}\right)\right]\right. \\
\frac{d \ell_{1}}{d \hat{\ell}_{2}}=(1-\rho)\left[\frac{u_{C \ell}\left(C_{2}, \hat{\ell}_{2}\right)}{u_{C C}\left(C_{2}, \hat{\ell}_{2}\right)}\right] \frac{d \ell_{1}}{d I_{0}}
\end{gathered}
$$

